\title{
Methods for Calculating the Transfer Functions of Broadband Plate Piezoelectric Transducers with Transition Layers
}

\author{
S.A. Naida*, T.M. Zheliaskova, A.S. Naida, H.A. Kliushnichenko, A.V. Damarad
}

\author{
National Technical University of Ukraine "Igor Sikorsky Kyiv Polytechnic Institute", 37, Peremohy Ave., \\ 03056 Kyiv, Ukraine
}

(Received 10 October 2021; revised manuscript received 14 December 2021; published online 20 December 2021)

\begin{abstract}
The work considers broadband ultrasonic piezoelectric transducers for medical diagnostic echoscopes, ultrasonic therapeutic devices, which are widely used for the diagnosis and treatment of various diseases in medicine. Such piezoelectric transducers provide a bandwidth that covers almost the entire operating range of single-frequency electroacoustic transducers, specifically 1.4 to $18 \mathrm{MHz}$ for diagnostic devices and 1 to $3 \mathrm{MHz}$ for therapeutic devices. The use of broadband piezoelectric transducers significantly expands the capabilities of ultrasound devices. With the help of a $4.5-18 \mathrm{MHz}$ band scanner, it becomes possible to obtain an image of the spinal canal, the possibility of which has not even been discussed before. Therapeutic devices become more effective, and at the same time, their safety increases by eliminating the possibility of the formation of standing waves in the broadband mode. In this work, a method was chosen for expanding the band of a piezoelectric transducer using acoustic layers and electrical circuits, and the features of their medical application were taken into account: the load of piezoelectric transducers on a medium with low impedance and high attenuation - biological tissue - and operation in the echo mode. In all of the above applications of broadband piezoelectric transducers, the transfer function parameter becomes important, that is, the ratio of the input action to the output one. The purpose of the work is to obtain expressions for the transfer functions of wideband piezoelectric transducers of various designs with one or two transition layers. The calculation of the piezoelectric transducer transfer functions was carried out by two methods: the wave equation method, which is characterized by the need to solve a system consisting of a large number of equations even with a small number of transition layers, and on the basis of A-matrices of the regular line segment. It is shown that these two methods give the same calculated ratios, but the second method is more convenient for calculations.
\end{abstract}

Keywords: Ultrasound, Broadband piezoelectric transducers, Transition layers, Electrical circuits, Wave equation, Electromechanical four-pole.

DOI: 10.21272/jnep.13(6).06029

PACS number: $43.38 .+\mathrm{n}$

\section{INTRODUCTION}

Narrowband ultrasound (US) medical diagnostic scanners (echoscopes) and US therapeutic devices are widely used for the diagnosis and treatment of various diseases in medicine. For the first time, a person gets acquainted with US echoscopy in the womb during US examination of pregnant women. The World Health Organization (WHO) has asked to review the current policy of their routine US examination, and this has served as an additional stimulus for the further development of echoscopes. A new milestone in this direction was the emergence of broadband diagnostic echoscopes. In contrast to traditional single-frequency echoscopes, in which the operating range is covered by a set of variable narrow-band piezoelectric transducers (PTs), they use wide-band transducers.

The task of providing a wide frequency band has become especially relevant with the advent of wideband US echoscopes, covering the entire operating range of single-frequency PTs: from 1.4 to $18 \mathrm{MHz}$. An illustration of what the expansion of the PT frequency range gives can be the acquisition of an image of the spinal canal [1] using the $18 \mathrm{H} 5$ Transducer of the ACUSON Juniper Ultrasound System scanner from Siemens with a frequency band of $4.5-18 \mathrm{MHz}$ [1], the possibility of which has not even been discussed earlier.

A feature of the diagnostic application of US is the load of a PT on a medium with low wave impedance and high attenuation (biological tissues), as well as work in the echo mode.

The authors chose the method of expanding the PT band using acoustic layers and electrical circuits [2,3]. The latter is especially important for converters with linear scanning, in which the number of elements reaches hundreds, and adjustment of elements (usually connected in parallel with inductance elements) is used to equalize their characteristics.

US therapeutic emitters are widely used in medicine [4]. Those are usually made in the form of disks of high-quality piezoelectric ceramics of lead zirconate titanate and are placed in a waterproof shell made of aluminum or stainless steel, the reverse side of disks is adjacent to air. Contact with human skin is carried out either through a thin layer of contact liquid, or through an acoustically transparent bag with water, which can take the form of the irradiated part of the body. The radiation mode can be either continuous or pulsed. The operating frequency range from 1 to $3 \mathrm{MHz}$ in most US devices is covered by single-frequency emitters. They are intended for the treatment of the peripheral nervous system, musculoskeletal system, internal organs, dental, urological, obstetric and gynecological, as well as eye diseases.

It should be noted that to generate oscillations with

\footnotetext{
*nsa185921-ames@lll.kpi.ua
} 
frequencies of 1 and $3 \mathrm{MHz}$, PTs with the same thickness are used, only for generating $3 \mathrm{MHz}$ - the third harmonic. Although for radiation of the same power as at the first harmonic, we need to triple the voltage amplitude of the high-frequency generator.

A significant disadvantage of single-frequency therapeutic emitters, especially when working with the maximum permissible intensity and direct contact with the skin, which is not mentioned in the technical specifications, is the need to move them during the procedure [4]. This is caused by the necessity to avoid local damage to biological tissues due to the possible formation of standing waves and "hot spots".

To obtain a uniform ultrasonic beam in the cross section, it was proposed, as it is used in pulsed flaw detection of materials and in US medical scanners, to use sources with a wide spectrum of radiation. And as transducers, PTs of variable thickness were proposed, that are used in flaw detection [4]. Not to mention the problem of creating a broadband emitter of sufficient intensity in a continuous mode, such transducers are unacceptable, since different parts of biological tissues in the cross section of the beam are irradiated with different frequencies. Therefore, in this case, preference should be given to plate-type PTs.

In all the above-mentioned applications of broadband PTs, such parameter of a PT as its transfer function becomes important, that is, the ratio of the input action to the output one. For uniform vibrations of the piezoelectric plate (uniform distribution of the amplitudes of the vibrational velocity over the surface of the piezoelectric plate), it is advisable to consider a pair of values as input and output effects of the PT: vibrational pressure-electric voltage [5].

The purpose of the work is to obtain expressions for the transfer functions of broadband PTs of various designs.

\section{CALCULATION OF THE TRANSFER FUNCTIONS OF PTS USING THE WAVE EQUATION METHOD}

The transfer function of a PT operating in the ultrasonic wave emission mode (piezoelectric emitter) is determined by the expression [5]:

$$
K_{\text {Rad }}=\frac{p}{U_{\text {in }}},
$$

where $p$ is the oscillatory pressure at the acoustic output, $U_{\text {in }}$ is the power supply voltage.

Accordingly, the transfer function of a PT operating in the ultrasonic wave receiving mode (piezoelectric receiver) is expressed as follows:

$$
K_{\text {Rec }}=\frac{U_{o u t}}{p},
$$

where $U_{\text {out }}$ is the electrical voltage on the transducer electrodes, $p$ is the oscillatory pressure in the working environment without a piezoelectric receiver.

The values of the transfer functions at fixed frequencies are called transducer transfer coefficients [5].

When there are no losses and distortions of the sig- nal in the working environment (caused by absorption, diffraction, etc.) and the transfer function is characterized only by the properties of the PT, then the transfer function of the transducer operating in the radiationreceiving mode will be:

$$
K=K_{R a d} K_{R e c}
$$

In general, transfer functions are complex quantities that are expressed by amplitude-frequency $K(\omega)$ and phase-frequency $\varphi(\omega)$ characteristics [5]. Both $K(\omega)$ and $\varphi(\omega)$ characteristics are especially important in the analysis of broadband PTs, where the wave equation method is preferable to the method of equivalent circuits for finding transfer functions [6]. A characteristic feature of the wave equation method is the need to solve a system consisting of a large number of equations even with a small number of transition layers.

Then, we present the expressions for the transient response obtained by the wave equation method for the case without layers from [6], where generalizing formulas are given without intermediate calculations for the case of transducers with transition layers, obtained on the basis of relations for long lines.

The main system of equations, including the equations of motion, the direct and inverse piezoelectric effect (where the deformation $S=\partial \xi / \partial z$ and the electric field strength $E$ are taken as independent variables), and the equations of electrostatics, has the form:

$$
\left\{\begin{array}{l}
\rho_{0} \frac{\partial^{2} \xi}{\partial t^{2}}=\frac{\partial \sigma}{\partial z} \\
D=e_{33} \frac{\partial \xi}{\partial z}+\varepsilon_{33}^{S} E \\
\sigma=c_{33}^{E} \frac{\partial \xi}{\partial z}-e_{33} E \\
\frac{\partial D}{\partial z}=0
\end{array}\right.
$$

where $\rho_{0}$ is the density of the material of the piezoelectric element, $\xi$ is the displacement of the piezoelectric plate particles in the direction of the $O z$-axis, $\sigma$ is the elastic stress describing the field of elastic deformations, $\varepsilon_{33}^{S}$ is the dielectric constant of the clamped piezoelectric plate, $c_{33}^{E}$ is the elasticity constant at constant electric field strength, $e_{33}$ is the piezoelectric constant, $D$ is the electrical induction.

System (2) is solved in the case if

$$
z=0, l_{0} ; \quad \sigma \pm z_{a}^{ \pm} \frac{\partial \xi}{\partial t}=0, \quad U_{0} Y_{E}+A_{0} \frac{\partial D}{\partial t}=0,
$$

where $z_{a}^{ \pm}$is the resistance of acoustic loads applied to the ends of the piezoelectric element $z=0, l_{0}, l_{0}$ is the piezoelectric plate thickness, $Y_{E}$ is the conductivity of the electrical load on the active element, $A_{0}$ is the piezoelectric element surface area, $U_{0}$ is the voltage applied to the piezoelectric element.

With a harmonious dependence of the sought quantities on time, the solution to the boundary value problem (2), (3), that is, the transfer function of the PE, has the form: 


$$
K_{R a d} e^{i \varphi_{R a d}}=\frac{-\sigma(l)}{U_{0}}=\frac{e_{33}}{l_{0}} \frac{\alpha_{a}^{+}}{1+\alpha_{a}^{+}} \frac{(1-a)\left(1-a v^{-}\right)}{\Delta_{0}-\Delta_{1}},
$$

where $z_{0}=\sqrt{c_{33}^{D} \rho_{0}}$ is the PT wave resistance, $c_{33}^{D}$ is the elasticity constant at constant electric induction $D$, $a=e^{-i l_{0} k}, k=\frac{\omega}{c_{0}}, c_{0}$ is the phase velocity of ultrasonic wave distribution in the piezoelectric plate at constant electric induction $D$,

$$
\begin{gathered}
\alpha_{a}^{ \pm}=\frac{z_{a}^{ \pm}}{z_{0}}, \quad v^{ \pm}=\frac{1-\alpha_{a}^{ \pm}}{1+\alpha_{a}^{ \pm}}, \\
\Delta_{0}=1-a^{2} v^{+} v^{-}, \\
\Delta_{1}=\frac{\beta}{2 i k l_{0}}(1-a)\left[2+v^{+}+v^{-}-a\left(v^{+}+v^{-}+2 v^{+} v^{-}\right) .\right.
\end{gathered}
$$

\subsection{PT with One Transition Layer}

Now consider a PT with one transition layer of thickness $d_{1}$ and wave impedance $z_{1}$ (see Fig. 1). In this design, $z_{a}^{+}$is replaced by the input impedance of the layer with acoustic load $z_{2}$ at the end.

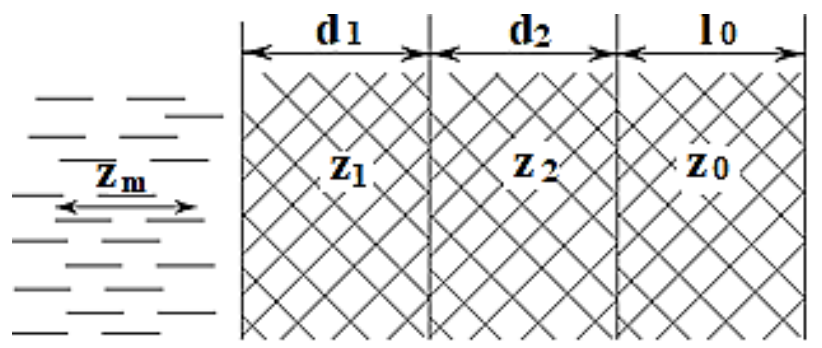

Fig. 1 - Schematic representation of the PT design

The distribution of pressure and velocity along the axis of the layer $z$ is as follows:

$$
\begin{aligned}
& \dot{p}(z)=\frac{1}{2}\left(\dot{p}_{2}+\dot{v}_{2} z_{1}\right) e^{i \beta\left(d_{1}-z\right)}+\frac{1}{2}\left(\dot{p}_{2}-\dot{v}_{2} z_{1}\right) e^{-i \beta\left(d_{1}-z\right)}, \\
& \dot{v}(z)=\frac{1}{2 z_{1}}\left[\left(\dot{p}_{2}+\dot{v}_{2} z_{1}\right) e^{i \beta\left(d_{1}-z\right)}-\left(\dot{p}_{2}-\dot{v}_{2} z_{1}\right) e^{-i \beta\left(d_{1}-z\right)}\right]
\end{aligned}
$$

Hence

$$
\begin{aligned}
& \tilde{z}_{1}=\frac{\dot{p}_{0}}{\dot{v}_{0}}=\frac{z_{1}\left(\dot{p}_{2}+\dot{v}_{2} z_{1}\right) e^{i \beta d_{1}}+\left(\dot{p}_{2}-\dot{v}_{2} z_{1}\right) e^{-i \beta d_{1}}}{\left(\dot{p}_{2}+\dot{v}_{2} z_{1}\right) e^{i \beta d_{1}}-\left(\dot{p}_{2}-\dot{v}_{2} z_{1}\right) e^{-i \beta d_{1}}}= \\
& =z_{1} \frac{1-a_{1}^{2} v_{12}}{1+a_{1}^{2} v_{12}}
\end{aligned}
$$

where

$$
v_{12}=\frac{z_{1}-z_{2}}{z_{1}+z_{2}}
$$

is the reflection coefficient of load $z_{2}$.

Thus, in (4), instead of $\alpha_{a}^{+}$we substitute $\alpha_{a}^{+} \rightarrow \frac{\tilde{z}_{1}}{z_{n}}$ :

$$
\tilde{v}^{+}=\frac{1_{1}-\frac{\tilde{z}_{1}}{z_{n}}}{1_{1}+\frac{\tilde{z}_{1}}{z_{n}}}=\frac{v_{n 1}+a_{1}^{2} v_{12}}{1+a_{1}^{2} v_{12} v_{n 1}} .
$$

To compare the results, let us return to the designations used in [7]:

$$
\begin{gathered}
z_{n} \rightarrow z_{1}, z_{1} \rightarrow z_{2}, z_{2} \rightarrow z_{m}, v_{12} \rightarrow V_{2 m}, V_{n 1} \rightarrow V_{12}, \\
a_{1} \rightarrow a_{2}, \tilde{v}^{+} \rightarrow \bar{V}_{1 m}, \\
\frac{\alpha_{a}^{+}}{1+\alpha_{a}^{+}} \rightarrow \frac{1}{2}\left(1-\tilde{v}^{+}\right)=\frac{1}{2}\left(1-\bar{V}_{1 m}\right), \\
\bar{V}_{m 1}=\frac{V_{12}+a_{2}^{2} V_{2 m}}{1+a_{2}^{2} V_{2 m} V_{12}} ; V_{12}=\frac{z_{1}-z_{2}}{z_{1}+z_{2}}=\frac{1-\alpha_{21}}{1+\alpha_{21}}, \\
V_{2 m}=\frac{z_{2}-z_{m}}{z_{2}+z_{m}}=\frac{\alpha_{21}-\alpha_{m 1}}{\alpha_{21}+\alpha_{m 1}} .
\end{gathered}
$$

Further, we obtain the transfer coefficient of one layer pressure from the PT surface to the load. For this, we use expression (5) if $z=0, \dot{v}_{2}=\frac{\dot{p}_{2}}{\dot{z}_{2}}$ :

$$
K_{p 1}=\frac{\dot{p}_{2}}{\dot{p}_{1}}=\frac{2 a_{1}}{1+\frac{z_{1}}{z_{2}}+a_{1}^{2}\left(1-\frac{z_{1}}{z_{2}}\right)}=a_{1} \frac{1-v_{12}}{1-a_{1}^{2} v_{12}}
$$

or in designations used in [7]:

$$
K_{p 1}=\frac{1-v_{2 m}}{1-a_{2}^{2} v_{2 m}} a_{2}
$$

Thus, with one layer:

$$
\frac{-\sigma_{\alpha_{1}}}{U_{0}}=\frac{l_{33}}{l_{0}} \frac{1-\tilde{v}^{+}}{2} \frac{(1-a)^{2}}{\Delta_{0}-\Delta_{1}} \frac{1-v_{12}}{1-a_{1}^{2} v_{12}} a_{1}
$$

or in designations used in [7]:

$$
K_{r}=\frac{p_{2}}{U_{0}}=\frac{l_{33}}{l_{0}} \frac{1-\bar{V}_{1 m}}{2} \frac{\left(1-a_{1}\right)^{2}}{\Delta_{0}-\Delta_{1}} \frac{1-V_{2 m}}{1-a_{2}^{2} V_{2 m}} a_{2} .
$$

\subsection{PT with Two Layers}

Consider the design of a PT containing two layers of thickness $d_{1}, d_{2}$ and impedance $z_{1}, z_{2}$ :

$$
\begin{gathered}
K_{p 1}=a_{1} \frac{1-\tilde{v}_{12}}{1-a_{1}^{2} \tilde{v}_{12}}, \tilde{v}_{12}=\frac{v_{12}+a_{2}^{2} v_{23}}{1+a_{2}^{2} v_{23} v_{12}}, \\
K_{p 2}=a_{2} \frac{1-v_{23}}{1-a_{1}^{2} v_{23}}, v_{23}=\frac{z_{2}-z_{3}}{z_{2}+z_{3}} .
\end{gathered}
$$

In designations used in [7]:

$$
K_{p 2}=a_{2} \frac{1-\tilde{v}_{23}}{1-a_{2}^{2} \tilde{v}_{23}}, \tilde{v}_{23}=\frac{v_{23}+a_{3}^{2} v_{3 m}}{1+a_{3}^{2} v_{3 m} v_{23}},
$$




$$
K_{p 3}=a_{2} \frac{1-v_{3 m}}{1-a_{3}^{2} v_{3 m}}, v_{3 m}=\frac{z_{3}-z_{m}}{z_{3}+z_{m}},
$$

or

$$
\begin{gathered}
K_{p 2}=a_{2} \frac{1-\bar{V}_{2 m}}{1-a_{2}^{2} \bar{V}_{2 m}}, \bar{V}_{2 m}=\frac{V_{23}+a_{3} v_{3 m}}{1+a_{3}^{2} V_{23} V_{3 m}}, \\
K_{p 3}=a_{3} \frac{1-V_{3 m}}{1-a_{3}^{2} V_{3 m}}, V_{3 m}=\frac{z_{3}-z_{m}}{z_{3}+z_{m}} .
\end{gathered}
$$

Analyzing the obtained expressions (15)-(18), we can conclude that $K_{p 2}$ and $K_{p 3}$ do not depend on $z_{1}$ to $\bar{V}_{m 1}$.

The transfer function of a two-layer PT is:

$$
\frac{P_{3}}{U_{0}}=\frac{l_{33}}{l_{0}} \frac{1-\bar{V}_{1 m}}{2} \frac{1-a_{1}^{2}}{\Delta_{0}-\Delta_{1}} a_{2} \frac{1-\bar{V}_{2 m}}{1+a_{2}^{2} \bar{V}_{2 m}} a_{3} \frac{1-V_{3 m}}{1-a_{3}^{2} V_{3 m}}
$$

where

$$
\bar{V}_{1 m}=\frac{V_{12}+a_{2}^{2} \bar{V}_{2 m}}{1+a_{2}^{2} V_{12} \bar{V}_{2 m}}
$$

Then, we check the values of $K_{p 2}$ in the case of one quarter-wave layer and $\left(K_{p 2}, K_{p 3}\right)$-two layers, if $x=1$, $x=\omega^{\prime} \omega_{0}, \omega_{0}$ is the $\mathrm{PT}$ antiresonant frequency.

1) According to (12):

$$
K_{p 2}=\frac{1-\bar{V}_{2 m}}{1-a_{2}^{2} \bar{V}_{2 m}}, a_{2}=j \frac{z_{m}}{z_{2}} .
$$

2) According to (17) and (18):

$$
K_{p 2} \cdot K_{p 3}=-j \frac{1-\bar{V}_{2 m}}{1+\bar{V}_{2 m}} \cdot(-j) \frac{1-V_{3 m}}{1+V_{3 m}}=-\frac{z_{3}}{z_{2}} .
$$

Now we conclude that if $x=1$, the layer pressure transfer coefficients do not depend on the wave impedances of the layers $z_{1}$ and $z_{m}$.

The PT sensitivity in ultrasonic wave receiving mode (at idle speed $Y_{l}=0$ ) is:

$$
\frac{U_{\mathrm{PT}}^{\prime}}{-\sigma_{0}}=\frac{l_{33}}{l_{0}} \frac{1+v^{+}}{z_{m}} \frac{(1-a)\left(1-a v^{-}\right)}{\left(\Delta_{0}-\Delta_{1}\right)\left(Y_{l}+Y_{\mathrm{PT}}\right)},
$$

where $Y_{\mathrm{PT}}=i w C_{0} \frac{\Delta_{0}}{\Delta_{0}-\Delta_{1}}$ is the PT conductivity, $Y_{l}$ is the conductivity of electrical load to the active element.

In the presence of two layers, expression (23) is multiplied by the layer transfer coefficient of the pressure from the load side, and $v^{+}$is replaced by $\tilde{v}^{+}(10)$. Since in the combined mode of operation of the PT the transmission coefficients of the layers during emission and reception in free space are equal to 1 , that is, $\left(K_{p 2} \cdot K_{p 3}\right) \cdot\left(K_{p 3} \cdot K_{p 2}\right)=1$, then

$$
\left(K_{p 3} \cdot K_{p 2}\right)=1 /\left(K_{p 2} \cdot K_{p 3}\right) .
$$

In designations used in [7] (if $v^{-}=1$ ):

$$
-K_{\mathrm{PT}}=\frac{l_{33}}{l_{0}} \frac{1+\bar{V}_{1 m}}{z_{1}} \frac{\left(1-a_{1}\right)^{2}}{\left(\Delta_{0}-\Delta_{1}\right)\left(Y_{l}+Y_{\mathrm{PT}}\right)} \frac{1}{K_{p 2} \cdot K_{p 3}}
$$

According to (22),

$$
\frac{1}{K_{p 2} \cdot K_{p 3}}=-\frac{z_{2}}{z_{3}},
$$

then

$$
\begin{gathered}
K_{p 1}=a_{1} \frac{1-\tilde{v}_{12}}{1-a_{1}^{2} \tilde{v}_{12}}, \tilde{v}_{12}=\frac{v_{12}+a_{2}^{2} v_{23}}{1+a_{2}^{2} v_{23} v_{12}}, \\
K_{p 2}=a_{2} \frac{1-v_{23}}{1-a_{2}^{2} v_{23}}, v_{23}=\frac{z_{2}-z_{\mathrm{PT}}}{z_{2}+z_{\mathrm{PT}}}, v_{12}=\frac{z_{1}-z_{2}}{z_{1}+z_{2}}
\end{gathered}
$$

If we use the same designations as in the radiation mode, then

$$
v_{12} \rightarrow v_{21}=-v_{12}, v_{23} \rightarrow v_{2 \mathrm{PT}}=-v_{\mathrm{PT} 1} .
$$

\section{DETERMINATION OF TRANSMISSION PRESSURE RATIO BASED ON A-MATRICES OF REGULAR LINE SECTION}

Consider the radiation mode:

$$
\begin{aligned}
\dot{p}_{1} & =\dot{p}_{2} \cos \beta_{1} l_{1}+i \dot{v}_{2} z_{1} \sin \beta_{1} l_{1}, \\
\dot{v}_{1} & =\frac{\dot{p}_{2}}{z_{1}} i \sin \beta_{1} l_{1}+\dot{v}_{2} \cos \beta_{1} l_{1}, \\
A^{(1)} & =\left(\begin{array}{lc}
\cos \beta_{1} l_{1} & i z_{1} \sin \beta_{1} l_{1} \\
\frac{i}{z_{1}} \sin \beta_{1} l_{1} & \cos \beta_{1} l_{1}
\end{array}\right) .
\end{aligned}
$$

Multiplying the matrices for the 1st and 2nd layers, and then replacing $\dot{p}_{2}$ by $\dot{p}_{3}, \dot{v}_{2}$ by $\dot{v}_{3}=\frac{\dot{p}_{3}}{z_{m}}$, we get an expression for $\frac{\dot{p}_{3}}{\dot{p}_{1}}$ :

$$
A^{(2)}=\left(\begin{array}{cc}
\cos \beta_{2} l_{2} & i z_{2} \sin \beta_{2} l_{2} \\
\frac{i}{z_{2}} \sin \beta_{2} l_{2} & \cos \beta_{2} l_{2}
\end{array}\right),
$$

$$
\begin{gathered}
A=A^{(1)} \cdot A^{(2)}=\left(\begin{array}{cc}
A_{11}^{(1)} A_{11}^{(2)}+A_{12}^{(1)} A_{21}^{(2)} & A_{11}^{(1)} A_{12}^{(2)}+A_{12}^{(1)} A_{22}^{(2)} \\
A_{21}^{(1)} A_{11}^{(2)}+A_{22}^{(1)} A_{21}^{(2)} & A_{21}^{(1)} A_{12}^{(2)}+A_{22}^{(1)} A_{22}^{(2)}
\end{array}\right)= \\
=\left(\begin{array}{ll}
A_{11} & A_{12} \\
A_{21} & A_{22}
\end{array}\right),
\end{gathered}
$$

$$
\left\{\begin{array}{l}
A_{11}=\cos \beta_{1} l_{1} \cos \beta_{2} l_{2}+i z_{1} \sin \beta_{1} l_{1} \frac{i}{z_{2}} \sin \beta_{2} l_{2}, \\
A_{12}=\cos \beta_{1} l_{1} i z_{2} \sin \beta_{2} l_{2}+i z_{1} \sin \beta_{1} l_{1} \cos \beta_{2} l_{2}, \\
A_{21}=\frac{i}{z_{1}} \sin \beta_{1} l_{1} \cos \beta_{2} l_{2}+\cos \beta_{1} l_{1} \frac{i}{z_{2}} \sin \beta_{2} l_{2}, \\
A_{22}=\frac{i}{z_{1}} \sin \beta_{1} l_{1} \frac{i}{z_{2}} \sin \beta_{2} l_{2}+\cos \beta_{1} l_{1} \cos \beta_{2} l_{2} .
\end{array}\right.
$$

Further

$$
p_{1}=A_{11} p_{3}+A_{21} v_{3}=A_{11} p_{3}+A_{21} \frac{p_{3}}{z_{3}}=\left(A_{11}+\frac{A_{21}}{z_{3}}\right) p_{3} .
$$


From the above formula:

$$
\frac{p_{1}}{p_{3}}=A_{11}+\frac{A_{21}}{z_{3}} .
$$

Then we get an expression for the transmission coefficient, which depends on $z_{3}$.

By doing the following substitution:

$$
\begin{gathered}
\cos \beta_{1} l_{1}=\frac{e^{i \beta_{1} l_{1}}+e^{-i \beta_{1} l_{1}}}{2}=\frac{\frac{1}{a_{1}}+a_{1}}{2}=\frac{1+a_{1}^{2}}{2 a_{1}}, \\
\cos \beta_{2} l_{2}=\frac{1+a_{2}^{2}}{2 a_{2}} \\
\sin \beta_{1} l_{1}=\frac{e^{i \beta_{1} l_{1}}+e^{-i \beta_{1} l_{1}}}{2 i}=\frac{1-a_{1}^{2}}{2 i a_{1}} \\
\sin \beta_{2} l_{2}=\frac{1-a_{2}^{2}}{2 i a_{2}}
\end{gathered}
$$

we get the expression:

$$
\frac{p_{3}}{p_{1}}=\frac{a_{1} a_{2}\left(1-v_{12}\right)\left(1-v_{23}\right)}{a_{2}^{2} v_{23}\left(v_{12}-a_{1}^{2}\right)+\left(1-a_{1}^{2} v_{12}\right)} .
$$

From formulas (13) and (14):

$$
\frac{p_{3}}{p_{1}}=K_{p 1} \cdot K_{p 2}=\frac{a_{1} a_{2}\left(1-v_{12}\right)\left(1-v_{23}\right)}{\left(1-a_{1}^{2} v_{12}\right)+a_{2}^{2} v_{23}\left(v_{12}-a_{1}^{2}\right)} .
$$

As a result, the two methods give the same calculation ratios. It should only be noted that the resolution of expressions (15) and (16) is shorter, but in practice, from the obtained expressions for calculating the transfer functions, expression (29) is the simplest.

\section{CONCLUSIONS}

The work presents a comparative analysis of the calculation of the PT transfer functions using the wave equation method and the electromechanical four-pole method. It is shown that the calculated ratios of the first method are simpler for the analysis and calculation of amplitude-frequency piezoelectric emitters for therapeutic devices. The calculated ratios of the second method are simpler when analyzing and calculating piezoelectric receivers, which may be relevant in such areas of application as passive acoustic diagnostic methods: measurement of the deep temperature of the human body with its acoustic thermal radiation [8]. In the case of PTs operating in the combined mode, as in an ultrasonic diagnostic echoscope, the electromechanical quadrupole method can be recommended.

\title{
REFERENCES
}

1. Siemens Healthineers. Transducers. ACUSON Juniper Ultrasound System.

2. N.V. Bogdanova, A.G. Leiko, S.A. Naida, A.I. Drozdenko, J. Nano-Electron. Phys. 11 No 6, 06011 (2019).

3. N.Y. Filipova, O.V. Korzhik, A.S. Chayka, S.A. Naida, M.O. Korzhik, A.S. Naida, J. Nano- Electron. Phys. 12 No 4, 04034 (2020).

4. M.F. Tereshchenko, H.S. Tymchyk, M.V. Chukhraiev, A.Iu. Kravchenko, Ultrazvukovi Fizioterapevtychni Aparaty ta Prystroi (Kyiv: Politekhnika: 2018) [In Ukrainian].

5. V. Domarkas, Je. Pileckas. Ultrazvukovaya Jehoskopiya (Lenynhrad: Mashynostroenye: 1988) [In Russian].

6. Pezokeramycheskye Preobrazovately: Spravochnyk (Red. S.Y. Puhachev) (Lenynhrad: Sudostroenye: 1984) [In Russian].

7. B.Ia. Kasatkyn, N.Ia. Pavyn, Akusticheskij Zhurnal 26 No 5, 721 (1980). [In Russian].

8. A.A. Anosov, A.S. Kazansky, P.V. Subochev, A.D. Mansfel'd, V.V. Klinshov, J. Acoust. Soc. Am. 137 No 4, 1667 (2015).

\section{Методи розрахунку передавальних функцій широкосмугових пластинчатих п'езоперетворювачів з перехідними шарами}

\author{
С.А. Найда, Т.М. Желяскова, А.С. Найда, Г.А. Клюшніченко, А.В. Дамарад
}
Національний технічний університет Украӥни "Київський політехнічний інститут імені Ігоря Сікорського, пр-т Перемоги, 37, 03056 Київ, Україна

В роботі розглядаються широкосмугові ультразвукові п'єзоелектричні перетворювачі для медичних діагностичних ехоскопів, ультразвукових терапевтичних апаратів, які широко використовуються для діагностики і лікування різних захворювань в медицині. Такі п'єзоперетворювачі забезпечують смугу частот, яка охоплюе майже увесь робочий діапазон одночастотних електроакустичних перетворювачів, а саме, від 1,4 до 18 МГц для діагностичних приладів і від 1 до 3 МГц для терапевтичних приладів. Використання широкосмугових п'єзоперетворювачів значно розширюе можливості ультразвукових приладів. Так, за допомогою сканера із смугою 4,5-18 МГц стає можливим отримання зображення каналу хребта, можливість чого до цього навіть не обговорювалася. А терапевтичні апарати стають більш ефективними, і при цьому, підвищуеться їх безпечність за рахунок виключення можливості утворення стоячих хвиль у широкосмуговому режимі. В роботі вибраний метод розширення смуги п'єзоперетворювача за допомогою акустичних шарів і електричних ланцюгів, та враховані особливості їх медичного застосування: навантаження п'єзоперетворювачів на середовище 3 малим хвилевим опором і великим загасанням - біологічну тканину і робота в ехо-режимі. В усіх згаданих вище застосуваннях широкосмугових п'єзоперетворювачів важливе значення набуває такий параметр, як їх передавальна фрункція, тобто відношення вхідного впливу до вихідного. Метою роботи є отримання 
виразів для передавальних функцій широкосмугових п'єзоперетворювачів різних конструкцій з одним або двома перехідними шарами. Розрахунок передавальних функцій п'езоперетворювача виконано двома методами: методом хвильового рівняння, характерним для якого є необхідність розв'язання системи, шо складаеться з значної кількості рівнянь навіть при невеликому числі перехідних шарів, і на основі А-матриць відрізку регулярної лінії. Показано, що два методи дають однакові розрахункові співвідношення, але другий е більш зручним для розрахунків.

Ключові слова: Ультразвук, Широкосмугові п'езоперетворювачі, Перехідні шари, Електричні ланщюги, Хвильове рівняння, Електромеханічний чотирьохполюсник. 